\title{
Religiosity in the Midst of the Wage System and the Fading of Ti'ayo in Gorontalo Tradition
}

\author{
Arfan Nusi, ${ }^{1}$ Fahimah M. Mooduto, ${ }^{2}$ Donald Q. Tungkagi. ${ }^{3}$ \\ 1,2,3Institut Agama Islam Negeri Sultan Amai, Gorontalo - Indonesia \\ e-mail: 1arfan nusi@yahoo.com; 2fahimahmooduto@gmail.com; \\ 3.donald.tungkagi@gmail.com
}

\begin{abstract}
People are very thick with the religious practices which combine religion and culture in Gorontalo. One of the religious spirits in the tradition is ti'ayo (community self-help). It is a farmer comes to everyone. It offers requests for helping others in the context of working together without wages in their garden. This cycle always occurs between one farmer and other farmers for decades. Also, cultivating the values of togetherness among farmers. Economically, ti'ayo tradition also reduces the cost of cultivating gardens. The source of the research was obtained from qualitative anthropological research. The data were obtained using observation techniques and indepth interviews. The aim is to see wage practices amid the fading ti'ayo tradition in the society of Gorontalo. The result is people's religiosity is slowly getting weaker. It is indicated since ti'ayo tradition replaced with a wage system. It also usually strengthens relationships and harmony among people and maintains brotherhood. However, this tradition has not survived until now; it seems that the community is living individually, between one farmer and others as if they have lost their sensitivity. The effect is the difficulty of the farmers in maintaining its life amid the onslaught of the wage system. The economic constraints of farmers are increasingly complex, including the borrowing capital from creditors with guarantees of garden or rice fields, instead of getting benefits from the harvest; precisely, they have to pay for the debts.
\end{abstract}

Keywords: Religiosity, Wages and Ti'ayo Tradition

\section{Introduction}

Indonesia should be grateful to be awarded thousands of islands, a plural society, and cultural diversity. One of the cultures that Indonesia should be proud of is gotong-royong. This culture has become one of the national identity because it is the basis of social solidarity of Indonesian people. The culture of gotongroyong has been around for a long time, even long before the country existed. It was born from the collective behaviour of the community arising from the cultural 
customs and customs of the archipelago. The value of gotong-royong is then transformed into a spirit and characteristic for the people of Indonesia.

Gotong-royong culture in Indonesia can be proven in various forms by the language and culture of the region in the Archipelago. The discovery of ancient relics such as stone dimples in North Sumatra, wooden dimples in Java and fishing boats in Southeast Sulawesi is evidence of the existence of this gotong-royong tradition to be an integral part of the civilization of Indonesian society. Gotongroyong activities in areas such as settlement development activities known as ngarawah or lewo (South Kalimantan), sambatan (Yogyakarta), landmarks (North Sumatra). There are also traditions of gotong-royong in the implementation of religious ceremonies/beliefs such as lepambai ceremony in Southeast Sulawesi, ngayah in Bali, kolo rai pemane ceremony in Nusa Tenggara, and molamoa ceremony in Central Sulawesi. ${ }^{1}$ While in Gorontalo the tradition of gotong-royong is known as Huyula with its various variants.

The tradition of gotong-royong in various regions also has its variants. Like the huyula (gotong-royong) tradition in Gorontalo Province which generally consists of three variants, namely: 1) Ambu, namely gotong-royong activities for the common good, such as the construction of village roads, village embankments, and bridges; 2) Hileiya is a spontaneous mutual activity that is considered an obligation as a member of the community, for example, assistance given to families who experience grief and other disasters; and 3) Ti'ayo which is a mutual activity between a group of people to do one's work, for example, agricultural activities, house building activities, and activities to build bantayo (tents) for wedding parties. ${ }^{2}$

Interestingly one of the variants in the tradition of gotong-royong (huyula) Gorontalo, namely the ti'ayo tradition lately is increasingly difficult to find, especially among the agrarian community, especially farmers in Gorontalo. This

${ }^{1}$ Halking, Hodriani and Julia Ivana, "The Culture of Gotong-royong of the Multiethnic Society in North Sumatra: How to Introduce it to Students through Civic Education?", Advances in Social Science, Education and Humanities Research (ASSEHR), Vol. 208, (2018), 333.

2Selengkapnya lihat Farah Daulima, Aspek-Aspek Budaya Masyarakat Gorontalo (Limboto: Banthayo Pobo'ide, 2004), 82. Rasyid Yunus, “Transformasi Nilai-Nilai Budaya Lokal Sebagai Upaya Pembangunan Karakter Bangsa," Jurnal Penelitian Pendidikan, Vol. 13, No. 1, (2013), 71. ISSN: p. 1412-565X e.2541-4135 
fact attracted the attention of researchers to trace the answer, as if the tradition of ti'ayo that became the identity of Gorontalo people slowly faded. Alleged author, the hegemony of the wage system in the middle of agricultural activities Gorontalo has ravaged the social capital tradition ti'ayo. Since the system was implemented, the noble culture of Gorontalo has become more and more integrated from the pulse of the peasant community. The ordinary of every farmer who wants to grow corn or other crops always ask for help (moti'ayo) to neighbours, relatives or relatives, now it has become taboo. Creating distance between farmers from one to the other. Their encounters in farm gardens are nothing more than interactions between landowners and waged land workers.

The author's anxiety is similar to the research findings of Farris Budiman Annas and Ekawati Sri Wahyuni. Their research report shows that about 38.1 per cent of Gorontalo farmers no longer know the local wisdom of ti'ayo. People who no longer know this tradition are generally from groups of young farmers who have never experienced this tradition firsthand have never even heard stories about ti'ayo. ${ }^{3} \mathrm{On}$ this basis, this research focuses on one of the variants of gotongroyong (huyula) in Gorontalo, namely the Ti'ayo tradition. Among the noble traditions is ti'ayo in Gorontalo. This tradition is considered in line with the teachings of religion, ti'ayo simply understanding help-help, hundreds of years of this tradition is cultured with Islamic culture that has been rooted in society, so it looks like this tradition is part of Islamic teachings.

Gorontalo province is one of the Muslim-majority provinces in Indonesia. About 98.27 per cent of the people of Gorontalo Province are Muslims. Population by religion in Gorontalo Province, Islam as many as 1,135,392 people, Protestants 12,550 people, Catholics 2,903 people, Hindus 3,872 people, Buddhism 661 people, and others 3 people. ${ }^{4}$ Naturally, local traditions in this area breathe the teachings of Islam. In line with tungkagi's findings, which found that historically the pattern of Islamization in Gorontalo is different from other kingdoms in the archipelago in general. The pattern of Islamization in Gorontalo in the form of "integration between Islam and Adat" since the initial period of Islamic encounter

${ }^{3}$ Farris Budiman Annas dan Ekawati Sri Wahyuni, "Analisis Eksistensi Kearifan Lokal Huyula Desa Bongoime Provinsi Gorontalo", Jurnal Penyuluhan, Vol. 10 No. 1 (2014), 1-12.

${ }^{4}$ BPS Provinsi Gorontalo, Provinsi Gorontalo dalam Angka 2020 (Gorontalo: BPS Provinsi Gorontalo, 2020), 231. 
with Gorontalo culture. 5 This is further strengthened by the existence of philosophical philosophy: "Adati hula to syaraa, syaraa hulahula to Qurani" which means Adat in the same shari'a, shari'a in the same Qur'an. It can be said that this philosophy indirectly confirms that the tradition in Gorontalo that survives today is in line with Islamic teachings or contains elements of Islamic teachings.

This article would like to show a more detailed point of view on how ti'ayo as a tradition containing the spirit of togetherness has emerged in Gorontalo. The article will not only retrace the cultural value of ti'ayo, but also how it develops and undergoes a shift due to socio-change in Gorontalo society. As a strong cultural value, this article also discusses how the tradition of ti'ayo is influenced by Islamic religious values, which also contribute to the history and culture of Gorontalo and its application in the daily life of the community.

\section{Research Methods}

This research is field research that uses qualitative descriptive analysis method, with an anthropological approach. This method describes the attitudes and views and situations or phenomena that occur when carrying out research. By carefully measuring certain social phenomena, in addition to describing the symptoms that occur. This research was conducted in Gorontalo, with the research subject being the farmer community. The data source used is primary data obtained through field studies and secondary data collected through literature studies, concepts, theories and other scientific works related to the problems studied. The key informants or subjects of this research are those who are considered to understand the problems of ti'ayo tradition, namely: Religious Leaders, Indigenous Leaders, Community Leaders and farmers. The data collection techniques used are in-depth interviews and focused group discussions. While data analysis in this study using Miles and Huberman consisting of data reduction, data presentation, conclusion drawing/verification through interactive methods.

5Donald Qomaidiansyah Tungkagi, "Varian Islam Nusantara: Jawa, Minangkabau dan Gorontalo", Jurnal Lektur Keagamaan, Vol. 15, No. 2, (2017), 273-294. DOI: $10.31291 /$ jlk.v15i2.524 


\section{Literature Reviews}

Researchers found it important to include review literature to determine the distinctive value between this study and relevant previous research. Some of the literature includes:

Nikolas Simarmata et al, in their research entitled "Gotong-royong in Indonesian History", found that the tradition of gotong-royong has been firmly rooted even in Indonesia since BC. This research concludes that the tradition of gotong-royong should be maintained as the life practice of Indonesian people. Because gotong-royong becomes a social adhesive contained in Pancasila, Bhineka Tunggal Ika, and in living a democratic life. ${ }^{6}$ This study examined mutual funds in a wide scope, as well as using historical approaches. This is what distinguishes the research in this article which specifically examines variants of the gotong-royong tradition in Gorontalo that are shifting due to social change influenced by anthropological approaches.

Tadjuddin Noer Effendi, in his research "Gotong-royong Community Culture in Social Change Today", outlines three main issues: gotong-royong as a squeeze of Pancasila and its application in social interactions of daily life, gotongroyong contains several elements of social capital as well as the condition of contemporary society that is in a situation of social chaos due to the weak application of mutual values in social interaction. ${ }^{7}$ The alleged rapid social change and strong pressure from outside, especially individualist attitudes are the cause of the shifting tradition of gotong-royong in line with the results of this research. However, there are differences in conclusions, namely, researchers see there are factors of the wage system that influence the tradition of ti'ayo in Gorontalo.

Idris Mahmudi, in his study "Islam, Gotong-royong Culture and Local Wisdom", concluded that the tradition of gotong-royong is local wisdom in line with Islamic teachings. In the Indonesian context, Islam does not come in a cultural vacuum, the existence of gotong-royong tradition has existed before the

${ }^{6}$ Nicholas Simarmata, Kwartarini Wahyu Yuniarti, Bagus Riyono, Bhina Patria, "Gotong-royong in Indonesian History", Digital Press Social Sciences and Humanities, Vol. 5, No. 6 (2020). https://doi.org/10.29037/digitalpress.45341

7Tadjuddin Noer Effendi, "Budaya Gotong-royong Masyarakat dalam Perubahan Sosial Saat ini”, Jurnal Pemikiran Sosiologi, Vol. 2 No.1, (2013), 1. 
arrival of Islam. ${ }^{8}$ The encounter of local traditions with Islamic teachings intertwined with mutually reinforcing acculturation is also the focus of the study of the author. The conclusion of this study, local wisdom such as huyula and ti'ayo in Gorontalo is appreciated because it does not contradict Islamic teachings.

Rashid Yunus through his research entitled "Transformation of Local Cultural Values as An Effort to Build The Nation's Character," examined the transformation of huyula value as the development of the nation's character in gorontalo city. The findings of this study show that huyula tradition contains the noble values of Pancasila can be used as a means of building the nation's character in the city of Gorontalo. ${ }^{9}$ Similarity with research in specifics of this paper focuses on examining the role of huyula tradition in the development of the nation's character but does not show a shift in huyula tradition due to social change in the current society. This research fills the blank space discussed in this study with a focus on studying one of the variants of huyula tradition, ta'iyo.

Furthermore, Farris Budiman Annas and Ekawati Sri Wahyuni examined the tradition of gotong-royong in Gorontalo with the research title "Analysis of the Existence of Local Wisdom huyula Bongoime Village Gorontalo Province." This study analyzed the existence of local wisdom huyula measured by the knowledge, attitude and behaviour of farmers to Huyula and its relationship with internal farmers and external factors. The samples were rice farmer workers in Bongoime village, Bone Bolango district, Gorontalo Province. This research uses quantitative data equipped with qualitative data. The results of this study show that the huyula tradition among the peasant community has been narrowed, especially in farmers in bongoime village this tradition is limited to cleaning irrigation channels. ${ }^{10}$ Similarity with this research is to see the shift of huyula tradition and had mentioned also the tradition of ti'ayo. The difference, in addition to the focus

8Idris Mahmudi, “Islam, Budaya Gotong-royong dan Kearifan Lokal”, Jurnal Penelitian IPTEKS, Vol. 2, No. 2, (2017), 138-147.

${ }^{9}$ Rasyid Yunus, “Transformasi Nilai-Nilai Budaya Lokal Sebagai Upaya Pembangunan Karakter Bangsa," Jurnal Penelitian Pendidikan, Vol. 13, No. 1, (2013), 67-79. ISSN: p.1412-565X e.2541-4135

${ }^{10}$ Farris Budiman Annas dan Ekawati Sri Wahyuni, "Analisis Eksistensi Kearifan Lokal Huyula Desa Bongoime Provinsi Gorontalo", Jurnal Penyuluhan, Vol. 10 No. 1 (2014), $1-12$. 
of research, is also the methodology used. The study also wants to confirm in the field that the shift in the tradition of ti'ayo is changing because of the wage system.

So far, the authors have found several similar studies that discuss various traditions of gotong-royong in local contexts in some areas. Even so, the researchers focused on taking some research results only as mentioned above with the consideration of the research that is most relevant to the research that the authors are currently working on.

\section{Conceptual Framework}

To express the local wisdom of gotong-royong huyula tradition, especially ti'ayo in Gorontalo based on various expert opinions. Here's an explanation of each of these opinions.

Gotong-royong is a cultural heritage of Indonesian people that have existed and developed in the social life of Indonesian people and passed down through generations. ${ }^{11}$ So entrenched gotong-royong tradition in Indonesian society manifested in the ethos of 'carrying together' without knowing the environment wherever it is:

"...Whether they are in a rural or urban environment, compassion and responsibility for humanity are deeply significant. In the Indonesian Archipelago, this ethos of 'carrying together' is the heart of the custom of gotong-royong (cooperation)".12

The term gotong-royong comes from the Javanese language. Literally, the word gotong means work and royong means together.13 So literally gotongroyong is doing work together. According to Sajogjo and Pudjiwati, gotong-

${ }^{11}$ Lihat bahasan Sartono Kartodijo, "Gotong-royong: Saling Menolong dalam Pembangunan Masyarakat Indonesia”, dalam Callette, Nat. J dan Kayam, Umar (ed), Kebudayaan dan Pembangunan: Sebuah Pendekatan Terhadap Antropologi Terapan di Indonesia (Jakarta, Yaysan Obor, 1987).

${ }^{12}$ Diana Butler, "Enlivening Cultural Environments Through Sharing and Gotongroyong (Mutual Cooperation)", Heritage of Nusantara: International Journal of Religious Literature and Heritage, Vol. 5, No. 1, (2016), 3.

${ }^{13}$ Baiquni Abdillah, Gotong-royong Cermin Budaya Bangsa Dalam Arus Globalisasi (Yogyakarta: STMIK Amikom, 2011), 7. 
royong is a cooperative activity between a large number of villagers to complete a particular project that is considered useful for the public interest. ${ }^{14}$

While Koentjaraningrat ${ }^{15}$ divides the two types of gotong-royong known by the People of Indonesia; gotong-royong please help and gotong-royong work devotion. Gotong-royong activities please help occur in agricultural activities, activities around the household, party activities, celebratory activities, and in the event of disaster or death. While the activities gotong-royong devotional work is usually done to do something ifatnya for the public interest, which is distinguished between gotong-royong on the initiative of citizens with forced gotong-royong. Koentjaraningrat further explained the types of gotong-royong in the countryside, namely: 1). Help in agricultural activities; 2) Help in activities around the household; 3) Help in party preparation and ceremony activities; and 4) Help in the event of accidents, disasters and deaths.

As explained in the introduction, the tradition of gotong-royong in Gorontalo is known as huyula. According to Daulima Huyula is "doing a job together by a group of people or members of the community in the sense of mutual help and reciprocity". Huyula for the people of Gorontalo its application can be seen in several types, namely: 1) Ambu is an activity to help for the common good or better known as the term of devotional work, for example making village roads, village embankments, bridges and so on. Also, ambu is one of the ways used by the community to solve problems in the community such as fights between citizens; 2) Hileiya is a spontaneous help and rescue activity that is considered an obligation as a member of the community, such as assistance given to families experiencing grief and other disasters; 3) Ti'ayo is a helpful activity between a group of people to do one's work, for example, agricultural activities, house building activities, bantayo building activities (tents) for wedding parties. ${ }^{16}$

The tradition of ti'ayo as the focus of this research study took place in the farming community in Gorontalo. Generally occurs in the social life of agriculture

\footnotetext{
${ }^{14}$ Sajogjo dan Pudjiwati, Sosiologi Pedesaan : Kumpulan Bacaan. Jilid 2 (Yogyakarta: Gadjah Mada University Press, 1982), 28.

15Koentjaraningrat, "Ciri-Ciri Kehidupan Masyarakat Pedesaan di Indonesia", dalam Sajogyo dan Sajogyo, Pudjiwati (ed.), Sosiologi Pedesaan, Jilid 1 (Yogyakarta : Gadjah Mada University Press, 1983).

${ }^{16}$ Farah Daulima, Aspek-Aspek Budaya Masyarakat Gorontalo (Limboto: Banthayo Pobo'ide Limboto, Fitrah, 2004), 82.
} 
ranging from the process of preparing the land, planting, to harvesting. Every family or community that wants to plant ask for help or ask for help (moti'ayo) to neighbours, relatives or relatives. It is enough to feed the workers during the day without paying any wages. The planting work is carried out jointly until completion.

But unfortunately, this tradition is slowly starting to be difficult to find in gorontalo society. The shift due to the social change of society is considered to be one of the causes. This is as revealed by Koentjaraningrat, that the thought of the values of dispossessed or change can occur when people's lives shift according to technological developments. ${ }^{17}$

Awareness of this condition and theoretical reflection leads us to the question of how ti'ayo tradition as one of the variants of gotong-royong tradition in Gorontalo that is bound by Islamic teachings and has undergone a cultural shift until it is endangered. The results and subsequent discussions of this article will discuss this in detail.

\section{Religious Value and Ti'ayo Tradition}

The religious value is at the center of ti'ayo tradition. Therefore, they affect their existence in people's lives. On the other hand, God's reciprocation is managed, and it also builds social solidarity among the people. The religious values in ti'ayo cannot be separated from the religious concept of society.

The existence of Islam in Gorontalo has a big influence on society's life. In this connection, religion is a system consisting of concepts which are believed and become the absolute belief of the people, as well as maintaining the human relationships with other humans. The value of ti'ayo reflects the togetherness in the society. It means that humans are social beings who cannot live alone without the involvement of other humans from various aspects of life.

The Islamic teachings on wata'aa wanu 'alal birri wattaqwa (help in kindness and piety) which gives great or beneficial values to life. It is like what has been reflected in ti'ayo tradition in Gorontalo society as the principle of togetherness which has the essential meaning of brotherhood. Besides it,

${ }^{17}$ Koentjaraningrat. Pengantar Ilmu Antropologi (Jakarta: PT. Rineka Cipta, 2002), 143-144. 
togetherness is built in helping and at the same time, binding a strong unity among the Gorontalo farmer communities. With this union, farmers become stronger and able to face various problems that arise.

The formation of farmer leaderless group reflects a society without the existence of sects in it. In the group, there is no differentiation among rich, medium and poor farmers. In other words, they have the rights and obligations to help each other among the group members.

\section{Ti'ayo among the Farming Community}

Ti'ayo is not the culture which contains the mystical or unseen values. On the contrary, it is the cultural habit which reflected in family values and values of unity regardless of Rupiah values.

The meaning of ti'ayo is temporary help when someone needs help. Then he can invite and ask for energy and facilities assistance from other people without having to respond directly to other people's help. ${ }^{18}$ The farming community in Gorontalo usually do ti'ayo when planting, plowing, and fertilizing until the harvesting process. The help is not based on a desire to get a reward, but it refers more to the values of harmony and togetherness in Gorontalo society.

Ti'ayo is the community self-help, ti'ayo boito hulondalo lio," said Kadullah. ${ }^{19}$ It means the community self-help is called ti'ayo (or mohuyula) from the Gorontalo society's version. It comes from the word "mongayo" which means ask, call or invite. In the implementation, the people who moli'ayo will invite the other residents to help them on the appointed day.

When the rain comes, the farmer who will plant corn and other plants, he will come to the other farmers' houses. It means he will invite and ask for help from other farmers. On the appointed day, they will come with their families. Meanwhile, he will prepare for the food and drinks to be consumed during the break time. Thus, this tradition will continue as a continuous cycle. Today A will help B, the next day B will help A.

${ }^{18}$ Sofyan Kau, Islam Tradisi dan Kearifan Lokal Gorontalo, (Gorontalo: Sultan Amai Press IAIN Sultan Amai Gorontalo, 2013), p. 71.

${ }^{19}$ Satria Kadullah, Pedagang Makanan, Interview on Thursday, on the 27 th of June, 2019. 
There are several forms of ti'ayo in Gorontalo society. First, farmers formed the farmer group and only them who involved in ti'ayo. It was like the farmer group that existed in Tapa, many times ago. It was the largest farmer group at that time revealed by Hamid Hasadi as the member of the group ${ }^{20}$. Second, ti'ayo without group or the form of tiayo which free to invite every farmer from wherever they are, to be called on the specified day to plant or harvest without any such group binding the peasants.

The family is indeed the foundation of this ti'ayo because the closest family usually invited in moti'ayo process. It can further strengthen the family relationship. Harmony among the families will be very visible when farmers and their families are sweating together while working. Laughter also adorns the atmosphere when taking a break time, reflecting the family values that get along well between one family and others.

\section{Farmer Community amid Wage System Problems}

Farmers are the class in society who act as the producer of raw food ingredients, but their existence in society is often considered a lower class in terms of their economy. This is no longer a public secret because in reality the majority of farmers are low-income farmers, and many of them are in debt to finance their garden or rice fields.

Processing costs are a burden that must be borne by farmers in large numbers, especially in the midst of monopoly capital which increasingly undermines of farmers' fatigue and sweat. Those are increasingly erratic in market prices. To get satisfactory yields, farmers have to pay for processing costs ranging from costs for the purchase of seeds, pesticides, and fertilizers, to the cost of providing wages for farm labourers. Farmers who do not have capital are forced to seek loans from creditors with an agreement to be paid at the harvest time. Usually, at that time, the farmers do not receive anything else because the harvest has been used to pay off the debts. "bolo mololimo nota,"21 said Irwan, a farmer in Suka Damai village, Lemito sub-district, which means that he only needs to receive a note because nothing is received anymore. The harvest is only enough

\footnotetext{
${ }^{20}$ Hamid Hasadi, Pemangku Adat, Interview on Thursday, on the 27th of June 2019.

21Irwan Lihawa, Petani Gorontalo, Interview on Sunday, on the 2nd of June 2019.
} 
to pay off the debt, even sometimes the debt will not be paid off due to failed harvests.

When viewed cooperatively, it turns out that most of the farmers seek loans for the cost of processing their gardens. So it can be drawn a red thread that the debthas accumulated is due to the high processing costs in farming. One of the most costly is wages for agricultural labourers. Usually, they are paid a daily (per day) per person and also a seed patch for a group of people. "For a wholesaler, one sack is two hundred and fifty thousand, but for a daily, one day is usually seventyfive, "22 said Irwan when he explained about the wage system in his village. Usually, he grew about three sacks of corn in his garden and had to pay a farm labourer from the village youth, with a total of seven hundred and fifty thousand. It was only in the planting stage, the costs that come out are quite large, not to mention the cost of fertilization to harvest.

The wage system is indeed a detrimental system to farmers. When compared with ti'ayo system, of course, the processing costs have to be borne by farmers will be reduced because there is no need to make wages can reduce more their incomes.

Ti'ayo can give benefit to the farmers. They do not need to pay workers. They only provide food for the workers. Therefore, the costs for workers' wages can be allocated for other financings. Thus, the farmers will not be in debt which is very burdensome.

Ti'ayo is a very influential tradition in terms of the economy of the farmers. For example, the farmers who have to pay workers 'wages can save much money because they don't have to pay workers' wages. Therefore, they can increase their incomes and farmers who used to only eat twice a day; can eat three times a day. There is no wage there, only help voluntarily among farmers. However, the current wage system has further dimmed the tradition. Whereas ti'ayo is very helpful for farmers who do not have the capital to farm. Most of them only have simple production tools. Therefore, maximizing crops is difficult without having to borrow money from a creditor.

Although the two traditions above (meaning huyula and ti'ayo) are symbols of togetherness and voluntary help seems to fade. It founded among

${ }^{22}$ Ibid. 
rural communities in the village of Denaa, Gorontalo District, such as in the activity of plowing gardens or rice fields. Unfortunately, the researchers found traditional activity such as ti'ayo is not based on the spirit of helping, but what happens is the workers receive some money. ${ }^{23}$

The temporary conclusion "the dimness of ti'ayo is the beginning of the farmer's life of wages and his life of wages is the death of ti'ayo. It is the wage system has killed ti'ayo culture in the life of the farmers because the emergence of the wage system has slowly changed their paradigm.

The researchers got information from Hasadi. ${ }^{24} \mathrm{He}$ revealed that in his era the group members were not only farmers but also employees who owned agricultural land. On the contrary, they did not have time to work on their land and were also part of the farmer groups they formed.

According to Hasadi, during the Old Order era, the word and historical evidence recorded the political parties and members recruited by the party were mostly peasants. It caused the members of the farmer groups to divide because of different parties. Besides it, it led to the destruction of the farmer groups. Just imagine a group used to have one viewpoint then experienced different political choices. Of course, in the group, there will be tremendous contradictions and bring the group's future to the brink of collapse.

Differences in attitudes and political choices have destroyed the intergroup unity which has been maintained by group members. Automatically, with the destruction of groups, the name of unity has been removed and replaced by the word division. Because the split occurred, the culture of helping each other in the process of cultivating the land or what is called ti'ayo slowly begin to disappear and farmers start working on their land individually or only with the help of their families.

The reason for the dimness of ti'ayo is raised again from the reason for the life of employees who own the land and do not have expertise. Even if they have the expertise, they do not have time to cultivate the land. This is a problem. They are people whose economy is quite advanced in society. Thereof, they are forced

${ }^{23}$ Sofyan Kau, Islam Tradisi dan Kearifan Lokal Gorontalo..., p. 71.

${ }^{24}$ Hamid Hasadi, Pemangku Adat, interview on Sunday, on the 23rd of June, 2019. 
to hire farmers to work on their land. This is where the "Wage System" emerged, which farmers have started to imitate until today.

However, it is different from the real meaning and reason for ti'ayo in the past and present. It cannot be maintained by society because of the wage system. Unfortunately, ti'ayo is rarely found in the life of farmers, only work and wages. It becomes a cycle which is always found today among farmers.

\section{The Spirit of Religion and Ti'ayo Tradition}

The commandments to help in religion are represented in the action of ti'ayo. Previously, the wage system hit the Gorontalo farmers, a high spirit of caring and helping attitude was reflected in the community. It means that the Gorontalo peasant community had implemented the spirit of Islam, as in Surat AlMaidah Verse 2:



"You the belivers, do not violate the syi'ar of Allah, and the honor of the haram months, do not (disturb) the animals had-ya, and the animals qalaa$i d$, and do not also disturb people who visit Baitullah while they are looking for the gift and pleasure of their Lord and when you have completed the pilgrimage, then you may hunt. And do not ever hate people because they prevent you from the Grand Mosque, encourage you to do persecution (to them). And help you in (doing) goodness and piety, and don't help in committing sins and transgressions. And fear Allah, Allah is very severe in punishment".

${ }^{25}$ Departemen Agama RI, Al-Qur'an dan Terjemahnya, (Semarang: Karya Toha Putra, 2002), p. 142. 
Ti'ayo tradition is included in the category of helping which contains precious values. It is said to be glorious because it helps fellow humans who need help to ease the burden on others. Thus, ti'ayo activity carried out customarily is essentially aimed at humanity. This local principle emphasizes the form of caring and kinship to further strengthen the relationship.

Yani states that the customs and traditions that exist in Gorontalo are not merely traditions. Yet, they have a foundation of a religious spirit which is firmly held by the community. They carry out the customs based on the principles of mutual respect, mutual joy, and mutual fun and helping each other. Because the Gorontalese is Muslims, ti'ayo tradition is carried out by Islamic teachings. ${ }^{26}$ In the other hand, according to Rustan, the principles of life followed by the community are based on the Islamic teachings. ${ }^{27}$ The connection with religious life is built from the belief in the power of the Creator who affects the lives of individual farmers.

Religion can bridge the problems of the wage system among Gorontalo farmers by re-echoing ti'ayo tradition. Because of its influence on the farmer's economy, ti'ayo has a big enough share in improving the farmer's economy. The lack of traditions in some areas of Gorontalo means that farmers have to bear large costs to pay wages to workers. The results in a decrease in income from their crops, they are in debt and even have to be willing to sell part of their lands to boost the family economy.

Could ti'ayo tradition be preserved again? There are two opinions from informants who were interviewed by the researchers in addressing the problem of preservation ti'ayo. Some people think that it is very difficult to even be resurrected, and can be resurrected.

"Oh., it is difficult because people get used to get the salary," stated Hasadi.28 This expression at the same time describes as if ti'ayo cannot be revived because people are used to wages. Even he also said that he is already used to the wage system which currently exists in Gorontalo society, today. He also states there was asense of dissatisfaction when the wages he received from the people who invited

${ }^{26}$ Abdurahman Yani, Tokoh Agama, interview on Sunday, on the 23rd of June 2019.

${ }^{27}$ Rustan, Tokoh Agama, interview on Sunday, on the 23rd of June 2019

${ }^{28}$ Hamid Hasadi, Pemangku Adat di Mo'odu, interview on Sunday, on the 23rd of June 2019.

JURNAL THEOLOGIA - Volume 31, Nomor 2, Desember 2020 
him were not like the wages he usually received. It is so because the wages would not be enough to support his family's needs.

Judging from the objective situation occurs in society; regarding the existence and proliferation of the wage system, of course, it changes the perspective of the farmers on how to meet needs and the perspective on unity and integrity. If you look at the condition of the people who are accustomed to the wage system, they have made it a source of income. On average, various areas already exist with a wage system. Some people who do not have agricultural land and jobs will still sell their energy during the planting seasons until harvest arrives. Not only applies to people who do not own land, but this also applies to farmers who tend to have low incomes. They are forced to sell their energy to get wages, which later will be used to finance agricultural processing and then part of the wages will be used to finance their needs household.

The other objective point of view assumes that ti'ayo still can be revived in understanding the developing situation and also the problems occur among Gorontalo farmers.

Based on the historical process, ti'ayo dimmed because it is turned off by the wage system which is the cause of the destruction of the unity and the peasants. Wontabe is different from Hasadi, who thinks about ti'ayo is difficult to be raised and even cannot be raised again. It happened because the wage system has taken rootin society. Saipul will not consider ti'ayo can be resurrected because he is aware of the resurrection of ti'ayo is not from a wage perspective, but the point of view of unity.

Saipul states ti'ayo still can be revived by reviving unity among the peasants. It is seen from the right point of view which is caused by the collapse of the unity and unity of the peasants. Then, of course, by reviving the unity has been in ruins, it will be able to revive ti'ayo which had been lost in a long time.

By re-establishing unity among the peasants, of course, they can return to ti'ayo tradition. The main key is unity and unity among the peasants. Unity is the key to cooperation. With the unity of the peasants, they are sure and believe that ti'ayo will rise. 


\section{Conclusion}

The change in society is a continuous process. It means the society has experienced changes on a scale, fast or slow. It is reflected in the changes in society, especially the shift in ti'ayo tradition towards a wage system which has been slow. This is the evidence from the fact that researchers still find Gorontalese familiarize themselves with the word ti'ayo verbally, even though the actual manifestation is $\mathrm{dim}$. The community understands the value of ti'ayo is contained in a bond of togetherness in kinship and unity. Moreover, the big contribution in improving the economy of the farming community is quite pronounced, because it reduces the expenditure on farming. Currently, the form of ti'ayo has shifted, changing to a wage system.

Therefore, it seems the religious spirit is needed. Thus, ti'ayo can return to resonance among Gorontalo peasant communities. To preserve this tradition, of course, religious and traditional leaders who are expected to play a role in taking concrete steps in manifesting this local wisdom.

\section{BIBLIOGRAPHY}

Al-Qur'an dan Terjemahnya. Semarang: Karya Toha Putra, 2002.

Abdillah, Baiquni. 2011. Gotong-royong Cermin Budaya Bangsa Dalam Arus Globalisasi. Yogyakarta: STMIKAmikom.

Annas, Farris Budiman dan Wahyuni, Ekawati Sri. 2014. "Analisis Eksistensi Kearifan Lokal Huyula Desa Bongoime Provinsi Gorontalo", Jurnal Penyuluhan, Vol. 10 No. 1.

BPS Provinsi Gorontalo. 2020. Provinsi Gorontalo dalam Angka 2020. Gorontalo: BPS Provinsi Gorontalo.

Butler, Diana. 2016. "Enlivening Cultural Environments Through Sharing and Gotong-royong (Mutual Cooperation)", Heritage of Nusantara: 
International Journal of Religious Literature and Heritage, Vol. 5, No. 1, (2016).

Daulima, Farah. 2004. Aspek-Aspek Budaya Masyarakat Gorontalo. Limboto: Banthayo Pobo'ide.

Effendi, Tadjuddin Noer. 2013. "Budaya Gotong-royong Masyarakat dalam Perubahan Sosial Saat ini”, Jurnal Pemikiran Sosiologi, Vol. 2 No.1, (2013).

Halking, Hodriani dan Julia Ivana. 2018. "The Culture of Gotong-royong of the Multiethnic Society in North Sumatera: How to Introduce it to Students through Civic Education?", Advances in Social Science, Education and Humanities Research (ASSEHR), Vol. 208, (2018).

Kartodijo, Sartono. 1987. “Gotong-royong: Saling Menolong dalam Pembangunan Masyarakat Indonesia", dalam Callette, Nat. J dan Kayam, Umar (ed), Kebudayaan dan Pembangunan: Sebuah Pendekatan Terhadap Antropologi Terapan di Indonesia. Jakarta: Yaysan Obor.

Kau, Sofyan. 2013. Islam Tradisi dan Kearifan Lokal Gorontalo. Gorontalo: Sultan Amai Press IAIN Sultan Amai Gorontalo.

Koentjaraningrat. 2002. Pengantar Ilmu Antropologi. Jakarta: PT. Rineka Cipta. . 1983. "Ciri-Ciri Kehidupan Masyarakat Pedesaan di Indonesia", dalam Sajogyo dan Sajogyo, Pudjiwati (ed.), Sosiologi Pedesaan, Jilid 1. Yogyakarta: Gadjah Mada University Press.

Mahmudi, Idris. 2017. "Islam, Budaya Gotong-royong dan Kearifan Lokal”, Jurnal Penelitian IPTEKS, Vol. 2, No. 2, (2017).

Sajogjo dan Pudjiwati 1982. Sosiologi Pedesaan : Kumpulan Bacaan. Jilid 2. Yogyakarta: Gadjah Mada University Press, 1982.

Simarmata, Nicholas, dkk. 2020. “Gotong-royong in Indonesian History”, Digital Press Social Sciences and Humanities, Vol. 5, No. 6 (2020). https://doi.org/10.29037/digitalpress.45341

Tungkagi, Donald Q. 2017. "Varian Islam Nusantara: Jawa, Minangkabau dan Gorontalo", Jurnal Lektur Keagamaan, Vol. 15, No. 2, (2017), 273-294. DOI: $10.31291 /$ jlk.v15i2.524 
Yunus, Rasyid. 2013. "Transformasi Nilai-Nilai Budaya Lokal Sebagai Upaya Pembangunan Karakter Bangsa," Jurnal Penelitian Pendidikan, Vol. 13, No. 1.71. ISSN: p.1412-565X e.2541-4135

Abdurahman Yani, Tokoh Agama, Wawancara pada Minggu, 23 Juni 2019.

Hamid Hasadi, Pemangku Adat, Wawancara pada Kamis, 27 Juni 2019.

Irwan Lihawa, Petani Gorontalo, Wawancara pada Minggu, 2 Juni 2019.

Rustan, Tokoh Agama, Wawancara pada minggu, 23 Juni 2019.

Satria Kadullah, Pedagang Makanan, Wawancara pada Kamis, 27 Juni 2019. 
ARFAN NuSI \& FaHIMAH M. MoOduTO: Religiosity in the Midst of the Wage System... 